\title{
E-Book Development at Kebonsari III Elementary School Tuban City
}

\author{
Anggun Winata ${ }^{1 *}$, Ifa Seftia Rahkma Widiyanti ${ }^{2}$, Saeful Mizan $^{3}$, Sri Cacik ${ }^{4}$ \\ 1,2,3,4 PGRI Ronggolawe University Tuban \\ *E-mail: anggunwinata@gmail.com
}

\begin{tabular}{lc}
\hline Submitted Article & Desember 29, 2019 \\
Reviewed Article & August 08, 2021 \\
Accepted Article & August 14, 2021 \\
\hline
\end{tabular}

\begin{abstract}
Information and Communication Technology (ICT) in education is one of the main supporters of educational services through the development of e-books. The purpose of this activity is to increase teacher competence in utilizing ICT to prepare the 21 st century education system in facing the industrial revolution 4.0. This activity uses the community development method through training, mentoring and development in the preparation of e-book learning media. Instrument achievement of implementation indicators using pretest and posttest questionnaires for knowledge and skills of e-book development for teachers at Elementary School Kebonsari III Tuban. Analysis of the results of achievement using descriptive analysis of the average value and percentage. The average pretest results of participants' abilities in developing e-books are still less visible from the results of less than $11 \%$, very less by $77 \%$, enough by $6 \%$, good $4 \%$ and very good by $2 \%$. The average posttest results of participants' ability in developing e-books increased, namely very less and less by $0 \%$, enough by $26 \%$, good by $60 \%$ and very good by $14 \%$.

The community development method is able to increase the knowledge and skills of teachers in developing ebook learning media
\end{abstract}

Keywords: Development, learning media, e-book, industry 4.0.

\section{INTRODUCTION}

The development of information and communication technology has grown quite rapidly and has affected all aspects of life, including the education aspect. Society in the current era is more focused on knowledge, as a consequence, all aspects of life experience changes and paradigm shifts. This paradigm shift certainly demands a fundamental change in the 21 st century education system. Information and Communication Technology in education is one of the main supporters of educational services. In realizing an independent, advanced, just and prosperous Indonesian society through strengthening the education system (human capital) and technological readiness (Bappenas, 2011).

Based on the above background, the progress of ICT must be followed by the ability of educators' resources in the using and developing of e-books as learning media. The survey results by the community service team showed that some teachers and administrators have not been able to utilize information technology as a learning medium, some and most of the internet/LAN networks do not yet have special software that supports learning activities and the lack of teachers' ability to create learning media independently .

Therefore, efforts are needed to increase knowledge and skills to develop learning media in the form of ebooks. It is hoped that this training can be accessed by participants because it is carried out online.

\section{GENERAL DESCRIPTION OF THE COMMUNITY, PROBLEMS AND TARGET SOLUTIONS}

\section{Community overview}

One of the teacher competencies is being able to utilize information technology to develop personal, pedagogical, social, and professional competencies in accordance with Permendiknas No. 16 of 2007 
concerning Teacher Competence. This is the basis of the achievement of the golden generation in 2045 and makes smart, creative and innovative students become human capital in Indonesia's social and economic development. In line with that, (Sykes, 2014) states that the characteristics of intelligent education are classes that are equipped with the right tools and technology and facilitate growing knowledge needs. Mastery of information technology is part of the demands of teacher competence, both to support the implementation of their duties (planning, presentation of learning, evaluation and analysis of evaluation results) as well as a means to find and download learning resources.

\section{Problem}

This activity is based on the results of previous research, the results show that teachers are still weak in the use of information and communication technology (ICT) media in the teaching and learning process (Rifdan, 2018). In line with the results of previous research, (Wernely, 2018) also stated that teacher competence was still low in terms of using ICT as a teaching medium. Based on the analysis of the situation above, the problems include: (1) the lack of ICT skills for teachers at Elementary School Kebonsari III Tuban, (2) there are still not many learning resources developed by teachers at SDN Kebonsari III Tuban.

\section{Troubleshooting Solutions}

The target of community service is carried out by random sampling of all Public and Private Elementary Schools in Tuban District. Based on the technique used by the community service team, the school obtained is SDN Kebonsari III Tuban. SDN Kebonsari III Tuban is located at Jl. Brawijaya No.62, Kebonsari, Kec. Tuban. This school really needs to do community service in improving ICT because the school is surveyed in the field, most of the teachers are still less competent in the use of ICT even though this school is a school located in a city area. One of the uses of information technology and technology for learning media is through the development of e-books, so that in its implementation it requires planning and design. (Sulistyaningrum: 2019) which consists of four stages, namely: 1) define, 2) design, 3) develop, and 4) disseminate (Thagarajan, et al., 1974

\section{METHODS}

The implementation of the service uses a community development approach with the aim of improving the skills of teachers to develop e-books as learning media through several stages. namely: (1) the preparation stage, and (2) the training implementation stage. In the preparatory stage, the things that were carried out included: (a) surveys to elementary schools in Tuban sub-district, Tuban district by distributing questionnaires about knowledge of learning resources, especially electronic learning resources, (b) determining locations and targets based on survey results, and (c) preparation of training materials/materials, which include: power point slides for e-book creation training activities. The survey to schools was carried out on September 2-20 2019, determining the location and target of community service on October 12, 2019, and preparing training materials/materials on October 14-11 November 2019. At the implementation stage, the things that were carried out included: (a) explanations related to e-books, (b) explanations related to the process of making ebooks, (c) training on how to compile materials in e-books, (d) assistance in completing the preparation of learning materials in e-books, (e) evaluating on the results of training and mentoring. The implementation phase at Elementary School Kebonsari III Tuban was held on 18-19 December 2019.

The population of the target community service is teachers in public and private elementary schools in the Tuban sub-district. While the target sample for community service is Elementary School Kebonsari III with the consideration that because of the school's survey in the field, most of the teachers are still less competent in the use of ICT even though this school is a school located in a city area.

The e-book training for teachers at Elementary School Kebonsari III Tuban uses sigil software because sigil has the advantages of (1) it is free and open source with a GPLv3 (open source) license and no need to buy a 
license to use it, (2) it is multiplatforms: can run on Windows, Linux and Mac, (3) multiple views: Book view, Code View and Preview, (4) it can directly edit the appearance of epub in book view, (5) table of contents generator with support for multi-level headings, (6) metadata editor, (7) it can not be corrupted, because the data is stored in the form of files, and (8) the publication process is cheap and easy to disseminate. After the implementation of the e-book development training, the community service team provided a questionnaire on the knowledge and skills of teachers in the use of ICT through analysis before and after the implementation of e-book development through pretest and posttest

\section{RESULTS AND DISCUSSION}

The implementation of community service has a positive impact on partners which can be seen from the results of questionnaire after the implementation of the e-book development training, namely many participants answered strongly agreed that (1) the training materials provided were based on the needs of the participants, (2) the training methods used were appropriate for the type of training, (3) the ability of the training instructor in providing training was as expected, (4) participants had high enthusiasm in training, (5) training could provide refreshment of the mind for participants, (6) participants were able to absorb the knowledge given after attending the training, (7) participants are able to absorb the knowledge of skills given after attending the training, (8) there is relevance of learning with the training that has been carried out. Based on the eight statement items, the 5th item, namely training can provide a refresher of the mind for participants, gave the highest result of $81.82 \%$ and the 8 th item, namely that there was relevance of learning with the training that had been carried out which gave the lowest result of $54.55 \%$.

Overall the results of the questionnaire after the training obtained results as shown in Figure 1.

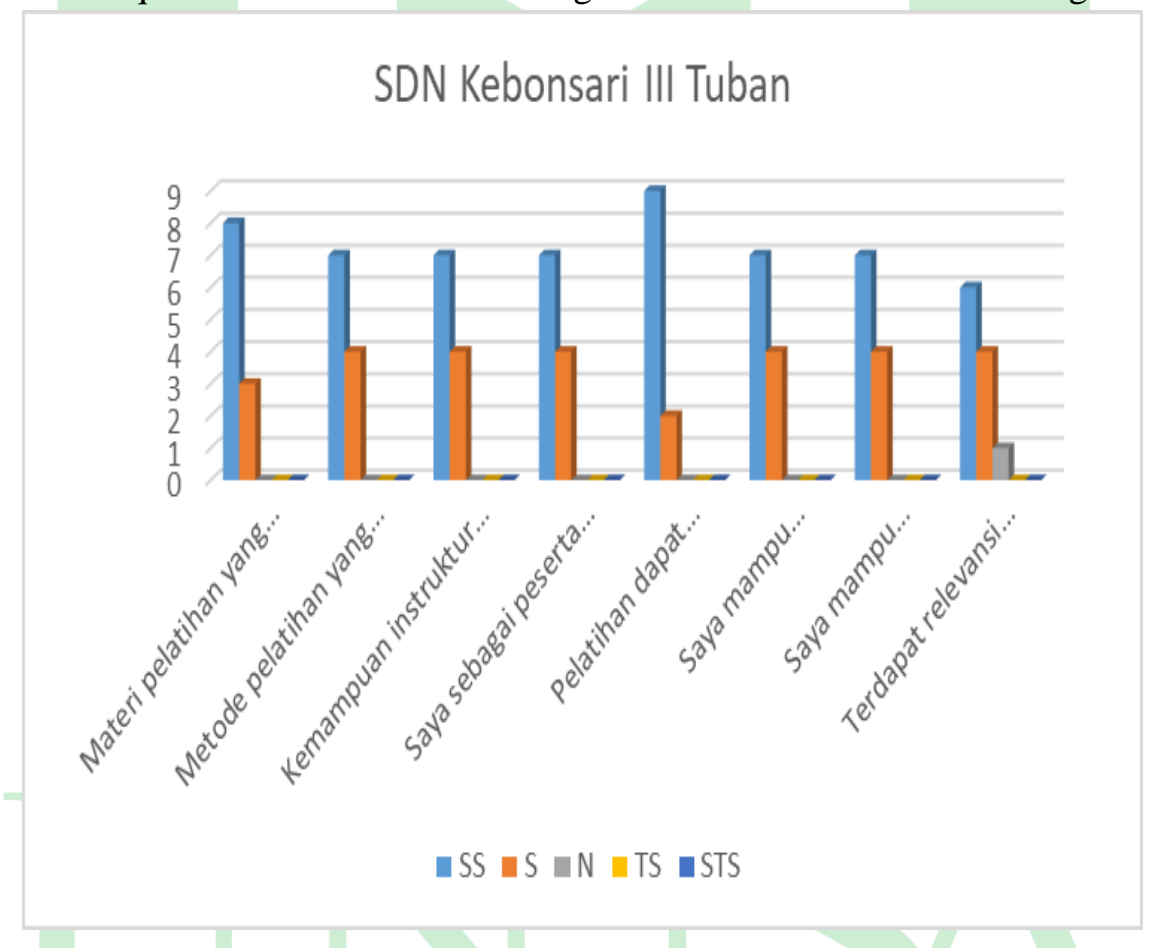

Figure 1. Response Results of E-Book Development Training Participant

The results of community service (Winata, et al., 2017), showed that the training participants showed high enthusiasm and gave a positive response. In line with that, the results of community service (Widiyanti, et al., 2017) show that training activities show a positive response from training participants both during question and answer and training including:

1. Improving knowledge and skills through the development of e-books. 
To find out teachers' increase knowledge and skills in the use of ICT, pretest and posttest questionnaires were filled out. The results of the e-book development pretest can be seen in table 1 .

Table 1. Results of the e-book development pretest

\begin{tabular}{lcccccc}
\hline & Material & \multicolumn{5}{c}{ Scale } \\
\cline { 2 - 6 } & & $\mathbf{1}$ & $\mathbf{2}$ & $\mathbf{3}$ & $\mathbf{4}$ & $\mathbf{5}$ \\
\hline Basic Microsoft word (Ms Word) & 0 & 0 & 5 & 4 & 2 \\
Convert Ms Word to Html & 1 & 10 & 0 & 0 & 0 \\
Install sigil & 2 & 8 & 1 & 0 & 0 \\
Inserting Html file into sigil & & 1 & 10 & 0 & 0 & 0 \\
Make a cover with ppt & 2 & 9 & 0 & 0 & 0 \\
Create a table of contents disigil & & 1 & 10 & 0 & 0 & 0 \\
Make a glossary disigil & 1 & 10 & 0 & 0 & 0 \\
Beautify the sigil & 1 & 10 & 0 & 0 & 0 \\
Installing ePub & 2 & 8 & 1 & 0 & 0 \\
Using e-books & 1 & 10 & 0 & 0 & 0 \\
\hline Ins
\end{tabular}

In general, the prior ability of the trainees the e-book development training was not able to master the e-book development as seen in the average results of the e-book development pretest in Figure 2.

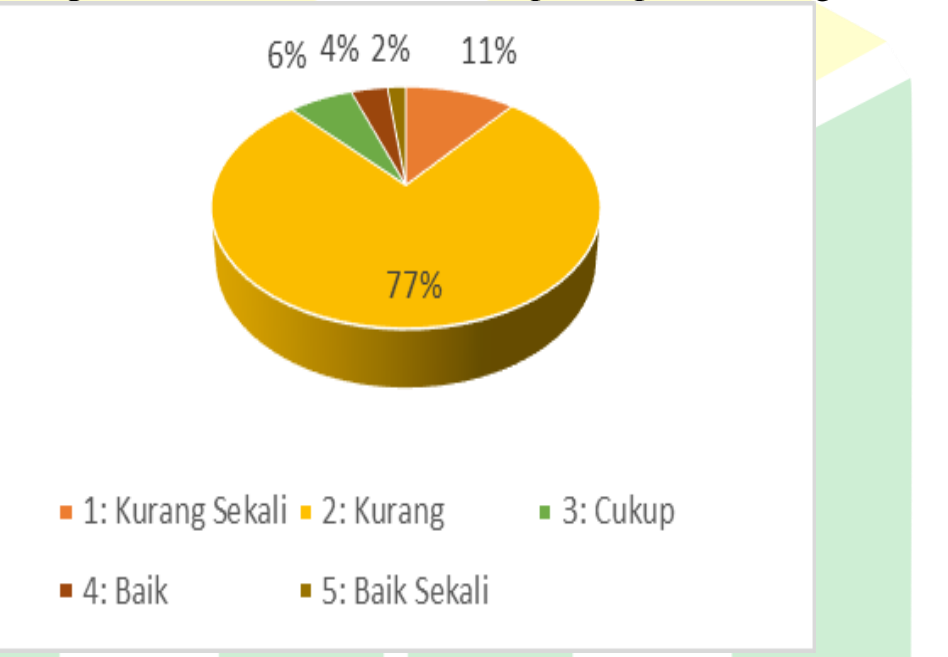

Figure 2. Average Pretest Results of e-book Development

The average pretest results of participants' abilities in developing e-books are still less visible from the results of less than $11 \%$, very poor at $77 \%$, sufficient at $6 \%$, good at $4 \%$ and very good at $2 \%$.

After 2 days of e-book development training, a posttest was given. The results of the posttest of e-book development can be seen in table 2 .

Table 2. Posttest results of e-book development

\begin{tabular}{lccccc}
\hline & Material & \multicolumn{4}{c}{ Scale } \\
\cline { 2 - 6 } & $\mathbf{1}$ & $\mathbf{2}$ & $\mathbf{3}$ & $\mathbf{4}$ & $\mathbf{5}$ \\
\hline Basic Microsoft word (Ms Word) & 0 & 0 & 2 & 5 & 4 \\
Convert Ms Word to Html & 0 & 0 & 3 & 7 & 1 \\
Install sigil & 0 & 0 & 2 & 8 & 1 \\
Inserting Html file into sigil & 0 & 0 & 3 & 7 & 1 \\
Make a cover with ppt & 0 & 0 & 1 & 8 & 2 \\
Create a table of contents disigil & 0 & 0 & 5 & 6 & 0 \\
Make a glossary disigil & 0 & 0 & 5 & 6 & 0 \\
Beautify the sigil & 0 & 0 & 5 & 6 & 0 \\
Installing ePub & 0 & 0 & 2 & 8 & 1 \\
Using e-books & 0 & 0 & 1 & 5 & 5 \\
\hline
\end{tabular}


In general, the ability of the training participants before the e-book development training was carried out was not able to master the e-book development as seen in the average results of the e-book development pretes Figure 3

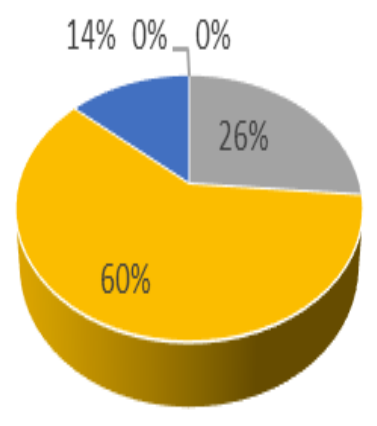

$$
\begin{aligned}
& \text { - 1: Kurang Sekali - 2: Kurang } \quad \text { - 3: Cukup } \\
& \text { - 4: Baik } \quad \text { - 5: Baik Sekali }
\end{aligned}
$$

Figure 3. Average E-Book Development Posttest Results

The average posttest results of participants' ability in developing e-books increased, namely very less and less by $0 \%$, enough by $26 \%$, good by $60 \%$ and very good by $14 \%$.

1. E-book innovation as a learning medium. The results of the e-book innovation by the participants can be seen in the pictures of the participants in the e-book development training on measurement materials. The following are the results made by participants as seen in Figures 4 and 5

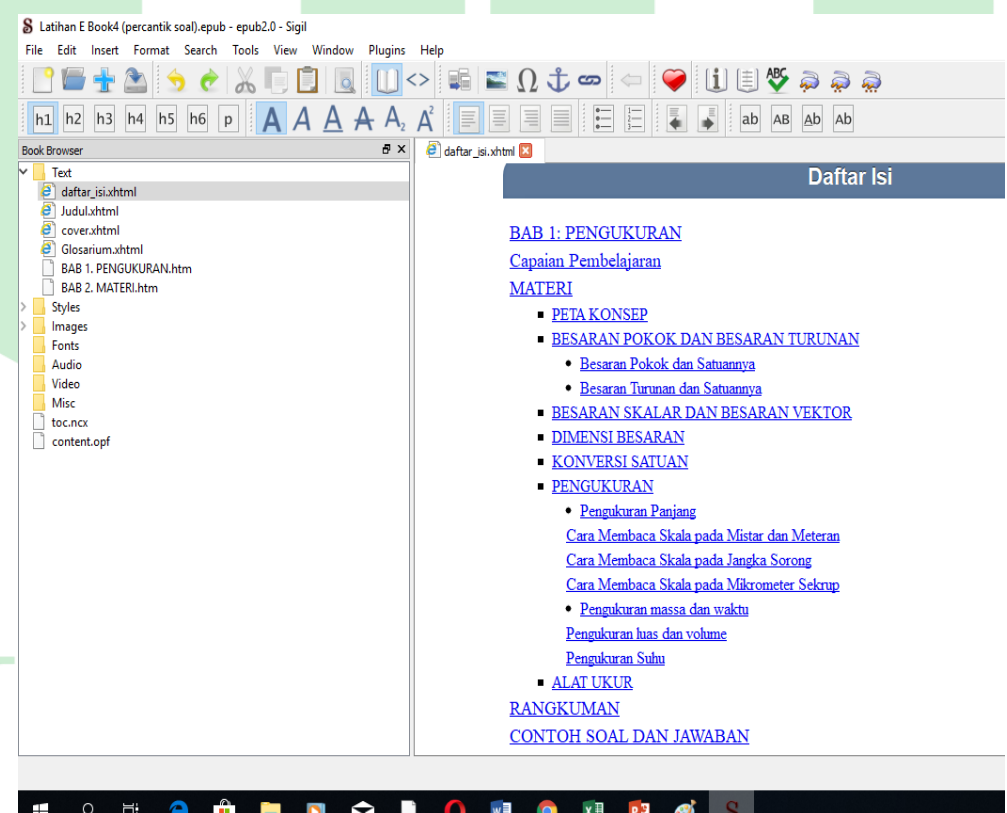

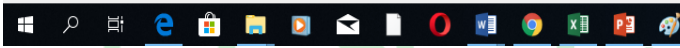

Figure 4. Results of the Participants' Table of Contents

It can be seen in Figure 4 that the training participants have been able to make a table of contents on the sigil application that has been taught by the Community Service Team. All participants have been able to practice making their own bibliography. 


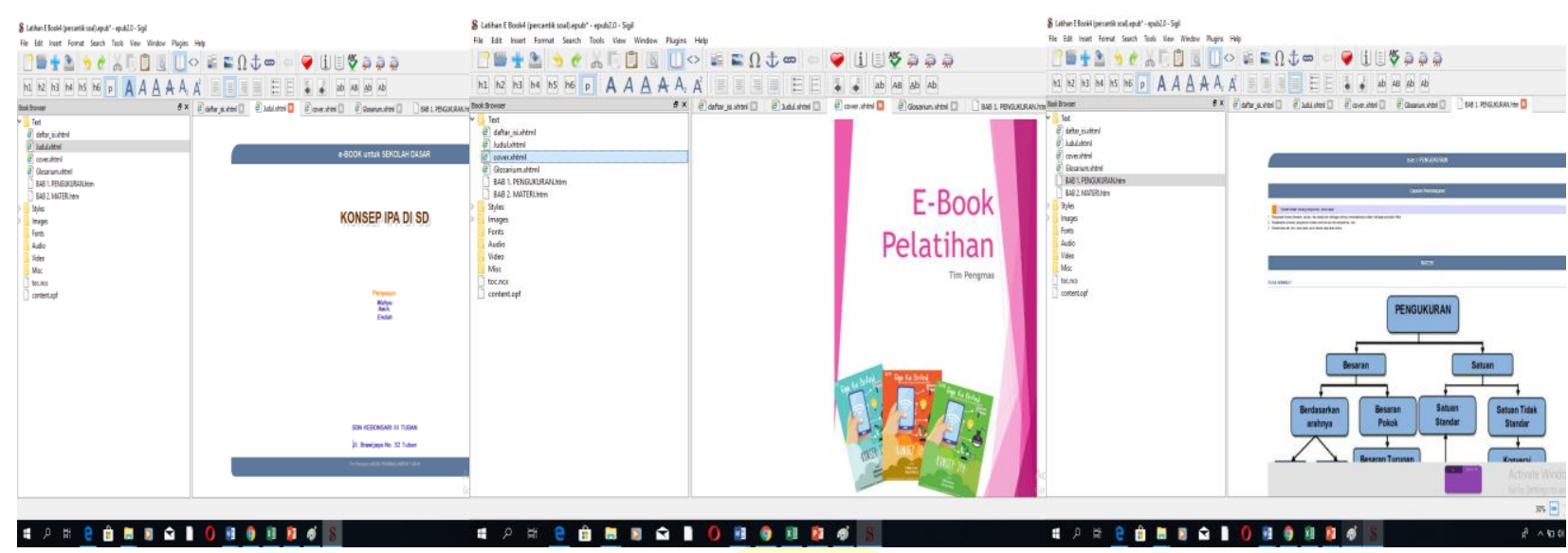

Figure 5. Results of Participant-Made Titles

It can be seen in Figure 5 that the training participants have been able to make a title on the sigil application that has been taught by the Community Service Team. All participants have been able to practice making their own titles. Not only that, some of the participants even modified it with a different look.

The training participants have been able to make a cover by making it on a power point that is entered in the sigil application that has been taught by the Community Service Team. All participants have been able to practice making their own covers and there are participants who modify it with other covers. The training participants have been able to make measurement materials on the sigil application that have been taught by the Community Service Team. All participants have been able to practice making their own material. There are participants who modify it by adding other material. Participants' e-book display that can be viewed in the Android application by installing ePub on the participant's Android cellphone and saving the sigil file that has been created on each participant's Android cellphone..

\section{CONCLUSION}

The community service program carried out by the UNIROW Community Service Team was able to provide several results, including the creation of synergy between UNIROW and Elementary School Kebonsari III Tuban. the enthusiasm of the training participants with the results of the questionnaire of more than $50 \%$ as well as increasing the knowledge and skills of teachers at Elementary School Kebonsari III Tuban in developing e-books

\section{REFERENCE}

BAPPENAS. 2011. Sustaining Partnership: Konektivitas Enam Koridor Ekonomi. Media Informasi : Edisi Khusus Konektivitas Nasional. Jakarta. websites: www.irsdp.org.

Kemendikbud Nomor 16 Tahun 2007 tentang tentang Kompetensi Guru.

Masita, E. D., Maimunah, S., \& Abidah, S. N. (2019). Pemanfaatan Rumah Keluarga Sebagai Kedasi (Kedai Support Asi) Menuju Zero Susu Formula Pada Bayi Usia 0-6 Bulan. Jurnal Pengabdian Masyarakat IPTEKS, 5(1), 13-21.

Rifdan. 2018. Upaya Meningkatkan Kemampuan Guru Dalam Penggunaan Media TIK Melalui Kegiatan Workshop Di Smpn 2 Teluk Kuantankecamatan Kuantan Tengah Kabupaten Kuantan Singingi. Jurnal PAJAR (Pendidikan dan Pengajaran) Program Studi Pendidikan Guru Sekolah Dasar FKIP Universitas Riau. 2 (5): 827-835.

Sulistyaningrum, H., Winata, A., \& Cacik, S. 2019. Analisis D1 Pengembangan Perangkat Pembelajaran Konsep IPA Berbasis Android Untuk Membangun $21^{\text {st }}$ Century Skills Mahasiswa. Prosiding Seminar Nasional Hasil Penelitian dan Pengabdian Masyarakat IV. 21 September 2019, Tuban, pp. 10-15. 
Sykes, E. R. 2014 . New Methods of Mobile Computing: From Smartphone to Smart Education, Tech Trends , 26-37.

Thiagarajan, Sivasailam, dkk. 1974 . Instructional Development for Training Teachers of Exceptional Children. Washinton DC: National Center for Improvement Educational System.

Wernely. 2018. Upaya Peningkatan Kemampuan Guru Dalam Penggunaan Teknologi Informasi Dan Komunikasi (TIK) Di TK Aisyiyah Kota Dumai. Jurnal PAJAR (Pendidikan dan Pengajaran) Program Studi Pendidikan Guru Sekolah Dasar FKIP Universitas Riau. 2 (3): 415-418.

Widiyanti, I. S. R., Cacik, S., \& Winata, Pelatihan Pembuatan Kapsul Biji Buah Alpukat (Persea Americana, Mill.) Sebagai Obat Diabetes Melitus. Prosiding Seminar Nasional UNIROW Tuban. 25 Februari 2017, Tuban. Pp 118-124.

Winata, A., Cacik., S., \& Mizan, S. 2017. Pelatihan Pembuatan Garbage Enzyme Di Desa Grabagan. Prosiding Seminar Nasional UNIROW Tuban. 25 Februari 2017, Tuban. Pp 140-145. 